\title{
Challenges of Cultural Relativism and the Future of Feminist Universalism
}

\author{
Bhabani Shankar Nayak ${ }^{1}$ \\ ${ }^{1}$ Glasgow School for Business and Society, Glasgow Caledonian University, Scotland, UK \\ Correspondence: Bhabani Shankar Nayak, Glasgow School for Business and Society, Glasgow Caledonian \\ University, W404, Hamish Wood Building, Scotland, G4 0BA, UK. Tel: 44-141-331-3316. E-mail: \\ bna1@gcu.ac.uk
}

Received: January 15, 2013 Accepted: February 20, 2013 Online Published: May 30, 2013

doi:10.5539/jpl.v6n2p83 URL: http://dx.doi.org/10.5539/jpl.v6n2p83

\begin{abstract}
The article seeks to explain and understand the contradictions within universalistic claims of feminism. It also highlights the challenges the Women's Movement is facing within the philosophical tenets of feminism. The paper begins by defining feminism and universalism from class and cultural points of view in relation to human rights. Then it analyzes not only the tensions between feminism and universalism (in relation to culture and class) but also shows similarities and parallels between them. This paper concludes by reviewing the challenges for Women's Rights as Human Rights from feminism. Taking into consideration class and cultural factors and challenges to Women's Universal Human Rights Movement, the paper argues that both must work together by making changes with regard to human rights (women and men) violations not only at the international level but also at national and local levels.
\end{abstract}

Keywords: feminism, universalism, culture, relativism and human rights

\section{Introduction}

The universalist claims of feminism in general and of the international feminist movement in particular owe their intellectual origin within the grand narratives of Marxian philosophy on the economic subjugation of women based on the gender division of labour. Men and women are defined differently in patriarchal and capitalist societies based on their access to or denials of productive resources based in both public sphere and private sphere. Kollontai (1927) in her forward to the English edition of her novel 'Red Love' writes about the way our societies deal with men and women. "The character of a man is evaluated not by his conduct in family morals, but by his efficiency in work, by his intellect, his will, his usefulness to the State and Society" but for women, it is all about her loyalties and "display of "good morals" in sexual and family life (ibid)". Economic subjugation of women is impossible without the bourgeois hypocrisy and its narratives of moral values; a mechanism of control life, labour and society. Patriarchal cultural norms are constructed to uphold structures of power that are detrimental towards the emancipation of women in general and materialise in the goals of women's right as human right in particular.

In recent years the issue of 'Women's Rights as Human Rights' (Okin, 1998) has increasingly gained prevalence and validity within the international community. However, the call for Women's Universal Human Rights appears not to avoid problems and challenges, even from the feminist movement itself. The challenge for women's rights as human rights is the question of "how can human rights be authorized in radically different societies without succumbing either to homogenizing universalism or the paralysis of cultural relativism? (Coomaraswami, 1994). It means the diversity of cultures in different societies stands as a threat to the human rights movement in general.

\section{The Nature of Feminism, Universalism, and Cultural Relativism}

Women's rights have become a centerpiece of international human rights debates in the last decade. An international commitment to universal human rights was made in 1945 under the United Nations Declaration of Human Rights, and in 1979 the Convention on the Elimination of All Forms of Discrimination Against Women (CEDAW) signified the status accorded to women's rights at the international level. Over 160 countries from all regions of the world and all religions have signed CEDAW (Chinkin, 1999). Though most feminists have 
claimed as a victory the inclusion of 'women's rights as human rights', problems have since emerged relating to the universal nature of the claim by feminists for women's rights. Feminism's primary aim in relation to human rights discourse has been to expand both the definition of who holds human rights, and to expand on what constitutes human rights; 'all strands of feminist critique aim at the inclusion of women in the human rights system' (Brems, 1997:141). Feminism advocates the incorporation of women's rights into the discourse of international human rights, and seeks to expand human rights to encompass women's concerns.

However, this incorporation of women's rights into human rights discourse varies from the appeal for the simple inclusion of women into the current human rights system, to the call by some feminists for a radical re-definition and re-formulation of human rights. Feminist critiques of human rights argue that the current dominant human rights discourse reflects the 'needs and aspirations of men,' (Mallick, 1998) and also argue that women's needs and aspirations need to be brought into human rights theory and practice. Feminism views human rights through a gendered lens, with an emphasis on the ways in which women experience human rights violations. Feminism requires the acknowledgement that women share some commonalities, regardless of their differences. These commonalities may include discrimination or oppression based on sex/gender and a critique of the patriarchal system. Feminists recognize that women around the world are more likely to experience poverty, domestic violence, and rape (Peach, 2001); thus, there is a need to work towards women's rights as human rights. The universalist human rights position argues that all human beings share the same inalienable rights (Mayer, 1995). Orend (2002:15) notes that 'every human being holds human rights' and that this commitment to universality is an inherent requirement of human rights. Universalists argue that human rights 'derive from the essence of humanity', and as such cannot be taken away (Bell, et.al, 2001). Therefore, it is argued that international principles can enforce basic human rights and compel states to alter their norms and treatments of citizens in order to comply with human rights. While those ascribing to a universal belief of human rights may acknowledge that cultures are different, they counter that similarities amongst individuals 'should prevail over cultural differences' (Bell, et. al, 2001). Cultural relativists argue that values and norms are specific to cultures, thus, there cannot be one set of universal values and norms on which human rights are based. Cultural relativists make the claim that human rights reflect Western values and norms, not those subscribed to by non-Western cultures (Mayer, 1995). Cultural relativists argue that societies and cultures should not be judged, and consequently condemned, for human rights violations based on relative Western values (Mayer, 1995). Cultural relativists point out that the Western oriented individual rights framework of human rights is not applicable to many non-Western cultures to which individual rights are a foreign concept, as these cultures are collective or group oriented (Mallick, 1998). Cultural relativists argue that by imposing universal norms and rights, one is only acting to bury cultural differences (Bunting, 1993). However, it should be noted that not all cultural relativists reject outright the entire concept of human rights; rather, many cultural relativists reject specific human rights claims or the specific context and interpretation of a rights claim (Brems, 1997). For human rights to be universal there is an inherent requirement that human rights themselves be viewed as universal. There is a fear amongst human rights advocates that cultural relativism can create 'paralysis' in the sphere of human rights and that it only serves as a barrier to enforcing human rights, especially those of women (Bunting, 1997). In addition, one must also recognize that though human beings are members of a particular cultural group, they are also 'members of an international or global community in which they have been recognized as bearing certain human rights' (Peach, 2001).

\section{Contradictions between Feminism and Cultural Relativism}

Feminists fear that cultural relativism will act as a barrier towards the increasing recognition of women's rights as human rights, and towards the enforcement of women's rights (Bunting, 1993). Due to this fear, the prevailing position amongst feminists, especially Western feminists, has traditionally been to oppose cultural relativism. Thus, there exist ongoing tensions between feminism and cultural relativism. Feminism calls for changes to be made to cultures so that they do not continue to discriminate against women, while cultural relativism counters that it is 'culturally appropriate' to ascribe specific roles to women and treat women in a particular manner (Brems, 1997). Bunting (1993) elaborates on the feminist position, stating that 'custom' is seen as something which perpetuates the subordination of women to men. Culture is seen as an impediment to the implementation of universal norm. This resistance by feminists towards cultural relativism is furthered by Rao (1995) who states, 'no social group has suffered greater violation of its human rights in the name of culture than women'.

Feminists often view cultural relativism as the continuation of male dominance and women's oppression (Brems, 1997). This tension has meant that the furthering of women's rights as human rights, has often been directly at the expense of cultural relativists' claim and cultural diversity. Nowadays, it is generally observed that numerous tensions still exist between feminism and cultural relativism. In many cultures women's position in the society is 
viewed as integral to the continuation and assertion of culture; 'women are exalted as the custodians of culture, the spiritual center of the nation' (Coomaraswamy, 1999). Cultures are thus often defined by the roles they ascribe to women (Chinkin, 1999). This is the reason why those who support a cultural relativist position are often most resistant to women's universal human rights. As women are often viewed as symbolically representing culture (Rao, 1995), any alteration to women's role and status within the society is viewed as an alteration to the foundation of the culture itself. Elmadmad (2002) argues that in most Muslim societies today, there are norms related to women and families that primarily characterize these societies as Islamic.

In addition, women's roles in many cultures are primarily relegated to the private sphere which is also viewed as central to culture, and therefore, an aspect of culture which should not be penetrated by international norms. Thus women's human rights, which threaten to pierce the impermeable private sphere of culture, are seen as especially threatening by those claiming cultural relativism. Another source of tension for feminism in relation to cultural relativism depends on who is making cultural relativist claim?. Feminists argue that it is often elite men, who are in control of the state or society, who make claims of cultural relativism. Feminists point out that when male leaders make claims of cultural relativism, it is often in defense of a custom which is oppressive towards women (Rao, 1995:17). Rao also states that when a claim of cultural relativism is made one must ask 'what is the status of the speaker making the claim,' and 'in whose name is the argument for cultural relativism being advanced'. Feminists also argue that though these male leaders claim to speak for the culture as a whole, the women whom the customs and human rights principles would affect are often silenced within the culture of male dominance and female acceptance. Mayer (1995) argues that states which make cultural relativist claims often go to extensive lengths in order to stifle women's voices, which are often of dissent and serve to discredit the claim of cultural relativism. Mayer further argues that some Islamic governments have even gone to the extent of outlawing feminist groups which challenge the dominant Islamic culture and, thus, threaten claims of cultural relativism. Chinkin (1999) points out that few advances for women in the realm of human rights will be made as long as it is male leaders, who argue that women's roles are integral to culture, speaking for women.

Another criticism made by feminists towards cultural relativism is that it is often the powerful and elite in society, most often men, who determine what is considered to be 'culture,' and thus, what can be defended from a cultural relativist perspective. Rao (1995) cautions that not all groups have the same access to culture or the same influence in the creation of culture. Mayer (1995) argues that the vision of culture articulated by the dominant elite in a society is not necessarily representative of all individuals within that culture; rather, culture is often challenged from below, from women and other marginalized groups. Singer (1999:47) argues that the international community should acknowledge that were women given the opportunity to determine what is integral to their culture, 'they would most likely reject the elites' version'. Feminists charge that claims of cultural relativism ignore the fact that cultures are not static and cohesive, but that they are multiple in nature and constantly evolving. Rao (1995:172) argues that culture is a 'series of constantly contested and negotiated social practices whose meanings are influenced by the power and status of their interpreters and participants'. Claims of cultural relativism also imply that maintaining a cultural practice is beneficial to the society as a whole, when in fact; the practice may only benefit certain segments of the culture. Feminists also find problematic the reservations made by countries to international human rights treaties, which nullify certain aspects of the human rights declaration in the name of culture and religion.

Many countries claim reservations against certain sections of a human rights treaty or declaration to which they are party, on the basis of cultural or religious grounds. Mayer (1995) notes that while reservations are not supposed to violate the principle aims and goals of a treaty, often reservations do just that. She cites the example of many Islamic countries reservations to CEDAW, in order to preserve Islamic culture and religion; yet the purpose of CEDAW was to 'change cultural constructs which were a barrier to women's equality' (Mayer, 1995:179). In the end, many feminist critics argue that the result of reservations is continued discrimination against women and that 'claims from diverse states and regions to culture turn out to have the same consequence - denying women equal rights' (Mayer, 1995:185). Mayer (1995:185) makes the claim that reservations based on cultural relativism are often 'nothing more than disguises for the universality of male determination to cling to power and privilege'.

\section{Universalism - Claims of Essentialism?}

Feminism has been dismissive of cultural relativism due to the tensions noted above, however, this absence of a cultural difference perspective has meant that women's rights have traditionally been formulated in an universalistic and essentialist manner (Bunting, 1993:6). It is alleged that feminists calling for universal human rights base their claim to rights on a Western, white middle class women's perspective. According to Elizabeth Grosz (Bunting, 1993:11), "essentialism entails that those characteristics defined as women's essence are shared 
in common by all women at all times". The claim by feminists for a universal women's experience, which is the basis for women's human rights is alleged to, 'assume that all women have similar attributes and experiences and ignore the impact of other variables such as race, class, wealth, and sexual preferences on the position of women' (Charlesworth, 1994:62). It is further argued, that while calling for the inclusion of women's rights, feminists have in fact excluded others on the basis of ethnicity, class, religion, and sexuality. Spelman (1988:3) cautions that 'any attempt to talk about all women in terms of something we have in common undermines attempts to talk about the differences amongst us'. Cultural relativists charge that the essentialist position taken by many feminists is merely another instance of Western values and norms being imposed on non-Western countries in an imperialistic and neo-colonial manner.

It has become increasingly difficult for feminists to ignore the allegations from cultural relativists that feminists' claims for human rights are Western based, as simultaneously feminists are claiming that human rights are male based. Bunting (1993:10) cautions that it is problematic for feminists to dismiss cultural relativism as it leads to a strategy of human rights which is only 'relevant to a minimum of women in the world'. She further argues that to dismiss cultural relativism is to ignore the simultaneous oppressions which may be present in the violation of women's rights. Based, on these realizations, many feminists are now re-examining cultural relativist arguments and new 'strains of feminism ... characterized by pluralism' are emerging which acknowledge the fact that the experiences of all women will not be identical (Elshtain, 1995:544). There is now an attempt by many stands of feminism to 'understand the world through the eyes of others' (Elshtain, 1995:557), and to recognize that women vary across class, ethnicity, age, ability, sexual orientation and culture.

\section{Feminism and Cultural Relativism - Similarities}

Emerging feminist theories which attempt to be non-essentialist have reduced tensions between feminism and cultural relativism (Brems, 1997:155). In fact, it is argued by some feminists, that feminism and cultural relativism actually have many similarities, and if the two groups could see beyond their differences, together they could provide a valuable critique of dominant human rights discourse. 'If cultural relativists and feminists stopped wasting their breath and energy on issues on which they are opposed and focused instead on issues they have in common, they could develop a powerful constructive human rights critique' (Brems, 1997:164). Both feminists and cultural relativists analyze human rights from a particular perspective and through a particular lens; feminists analyze human rights through a gender lens, while cultural relativists analyze human rights through the lens of culture. Feminists view the claim that existing human rights are universal as problematic as they see the present construction of 'universal' as deeply gendered, with women's concerns largely ignored, and the 'universal' premised on the needs and concerns of men (Bunting, 1993:8). Similarly, cultural relativists challenge the claim of universalism made by human rights, as they argue that human rights are culturally specific to Western norms and values, excluding the norms and values of non-Western cultures. Both feminists and cultural relativists view universal human rights as reflecting the values of a select few and excluding the perspectives of others, such as women and those from non-Western cultures.

Therefore, both feminists and cultural relativists call for the inclusion of their perspectives, gender and cultural diversity, within human rights discourse (Brems, 1997:154). Feminists and cultural relativists argue that in order for human rights to be the rights of all, they must not be gender or culture blind.

Feminists and cultural relativists also criticize the abstract theory which characterizes human rights discourse. Feminists call for a 'contextual and experiential' approach to human rights (Brems, 1997:141), while cultural relativists argue that the particularities of each cultural context must be recognized. Both feminists and cultural relativists call for a return to the particular context of gender or culture as the basis of analysis, whereby the 'abstract individual' is replaced within a 'situated, connected self' (Brems, 1997:156). Additionally, both feminists and cultural relativists criticize the priority given in human rights discourse towards civil and political rights, over social and economic rights. Feminists and cultural relativists argue that social and economic rights are of particular importance to women and non-Western cultures; thus, the priority given to civil and political rights is problematic and reflects the Western and male biases of human rights discourse.

\section{Future Challenges and Alternatives}

It is evident that there exist simultaneously both tensions and similarities between feminism and cultural relativism; therefore, many challenges remain in the future for women's rights as human rights. Clearly, in their appeal for women's rights, feminists face the challenge of trying to strike a delicate balance between the requirement that women's rights be universal for all women, and the particularities of cultural diversity which acknowledge the differences amongst women. This is a difficult balance for feminists who must 'avoid both elevating the experience of a specific group to the human 'norm,' and the relativistic paralysis of endorsing all 
pluralities and differences as morally and politically valid' (Brems, 1997:159). One possible reconciliation between these tensions may be the acknowledgement that the dichotomy between universalism and relativism is an artificial construct (Rao, 1995:168). An argument is made that universality does not necessarily require uniformity, therefore, human rights should be extended to be truly universal and inclusive of all (Brems, 1997:164). Brems (1997:163) proposes that while rights may be universal, the right to exercise them over culture is up to individuals; she states, 'each individual should have the right to practice his or her culture and traditions, but likewise, each individual should have the right to reject them'. There is also a proposal put forth that it is possible to change particular discriminatory practices within a culture, without changing the culture itself. Kisaakye (2002) argues that despite the fact that a discriminatory cultural practice may be altered, many other aspects of culture remain, such as food, language, dance, and clothing. Another potential solution is put forth in the notion that perhaps feminism itself can serve as a compromise between universalism and cultural relativism (Bell, 1999:151). Bell (1999:151) argues that feminist theory is beneficial as it succeeds in evading both 'homogenizing universalism or the paralysis of cultural relativism'. Elshtain (1995) echoes this argument stating that a global feminist consciousness can create feminisms which are unique to regions and develop from within women's existing culture, thus making feminism appropriate to the particular needs of women in various regions and cultures. Elshtain further argues that these feminisms, which originate in diverse regions, can serve to build bridges between dissimilar regions and cultures, without imposing one version of feminism on all women. Bunting (1993) also agrees with this line of thought, stating that feminisms must emerge which are particular to culture and region, in order that they can work against discrimination and oppression in ways which are culturally appropriate to their community. Some feminist theorists have come up with particular theories to address and reconcile the tensions between universalism and cultural relativism for feminists. One of them is Peach (2001) who develops a 'feminist pragmatic theory' about reconciliation of the tensions between universalism and cultural relativism within feminism, in which theory and practice are inseparable in the endeavor towards increasing and implementing women's rights. The primary consideration for Peach is which strategies of asserting women's rights are most effective in a particular context. She argues that in some contexts the approach of international human rights principles may be appropriate, while in other contexts this strategy would be ineffective as the framework for women to make rights claims does not exist within all cultures. Peach argues that in some contexts depending upon the presence of a 'rights consciousness', the risk of backlash against international human rights, the historical experience of others using a legal rights approach, and whether there is sufficient agreement amongst the affected women to claim a particular right, that in fact education, literacy, and communal ownership of land may grant more benefit to the affected women. Peach uses the example of Thailand, where women's rights are violated daily in the sex trade. Peach argues that merely asserting the fact that women's international human rights are being violated is of no benefit to the women in the Thai sex trade; women in Thailand remain in the sex trade as there are few opportunities for women to engage in waged employment. Thus, in this particular context Peach argues it would be most beneficial to implement strategies which provide alternate sources of waged employment for women. Pragmatically, feminist theory allows for human rights to be universally held by all women, however, it also allows for the acknowledgement of cultural diversity, as it recognizes that the assertion of these universal human rights may not always be the most effective strategy to empower women. Peach's pragmatic theory is well complemented by Donnelly's theoretical conception of human rights, in which he advocates for 'weak cultural relativism,' whereby strong universal rights exist, but there can exist in some cultural variation in the level of 'form' and 'implementation' (Donnelly, 1989:110). Similar to Peach's strategy, Donnelly (1989:124) argues that 'it may be necessary to allow limited cultural variations in the form and interpretation of particular human rights, but we must insist on their fundamental moral universality'.

While feminists must be cautious not to be essentialist in their claims for universal human rights, I would argue that, despite the differences and diversity amongst women, there also exist some commonalities. Lange (1993) argues that the predominant problem with essentialist critiques of feminism is that they 'disable feminism as a political movement'. Without some acknowledgement of the similarities amongst women, there exists neither the basis for either feminism, nor for the call of 'women's rights as human rights'. Peach (2001) argues that it is not essentialist to make claims on behalf of 'women' if one can demonstrate that there are in fact commonalities amongst women. She states that the devaluation of women's work, the feminization of poverty, and violence against women are commonalties shared by women around the world. Similarly, Charlesworth (1994:62) argues that there exist commonalities amongst women; she states that although manifested differently within different societies, patriarchy and the devaluation of women are 'almost universal'. Okin (1994) argues that while women of different classes, ethnicities, and regions may experience sexism slightly differently, they are still experience sexism. Okin further argues that while there are differences amongst women, gender remains an important 
category of analysis and argues that one should not be paralyzed by women's differences. Lange (1993:199) concludes that 'without some notion of women as a category of the oppressed, women stand to continue to be more silenced than men within the class, culture, race, or nation, where they find themselves'.

\section{Concluding Remarks}

While feminism must be cautious not to make essentialist claims of universality amongst women, one must also be cautious in the acceptance of cultural relativist claims. The question remains, how can human rights be 'authorized in radically different societies without succumbing to either homogenizing universalism or the paralysis of cultural relativism?' (Cook, 1994:7). Despite the fact that no definite conclusions have emerged in this analysis of feminism, universalism, and cultural relativism but still women's rights as universal human rights is the need of the hour. Though clearly international human rights must become more responsive towards the diversity of women, universal commonalities exist amongst women. These commonalities amongst women are the basis for the claim of 'women's rights as human rights.' In a more theoretical sense, we can argue that the 'self' shares its uniqueness and differences with 'others'; the 'other' is one among us. Therefore, the universalist claim of women's right as human right stands on a higher philosophical terrain.

\section{References}

Bell, C. (1999). Women's Rights as Human Rights: Old Agendas in New Guises. In A. Hegarty, \& S. Leonard (Eds.), Human Rights: An Agenda for the 21st Century. London: Cavendish Publishing Ltd.

Bell, L. S., Andrew J. N., \& Ilan, P. (Eds.). (2001). Introduction: Culture and Human Rights. In Negotiating Culture and Human Rights. New York: Columbia University Press.

Brems, E. (1997). Enemies of Allies? Feminism and Cultural Relativism as Dissident Voices in Human Rights Discourse. Human Rights Quarterly, 19(1), 136-164. http://dx.doi.org/10.1353/hrq.1997.0003

Bunting, A. (1993). Theorizing Women's Cultural Diversity in Feminist International Human Rights Strategies. Journal of Law and Society, 20(1). http://dx.doi.org/10.2307/1410109

Charlesworth, H. (1994). What are 'Women's International Human Rights'? In R. J. Cook (Ed.), Human Rights of Women: National and International Perspectives. Philadelphia: University of Pennsylvania Press.

Chinkin, C. (1999). Cultural Relativism and International Law.” In C. W. Howland (Ed.), Religious Fundamentalisms and the Human Rights of Women. New York: St. Martin's Press.

Cook, R. J. (1994), Women's International Human Rights Law: The Way Forward. In R. J. Cook (Ed.), Human Rights of Women: National and International Perspectives. Philadelphia: University of Pennsylvania Press.

Coomaraswamy, R. (1994). To Bellow like a Cow: Women, Ethnicity, and the Discourse of Rights. In R. J. Cook (Ed.), Human Rights of Women: National and International Perspectives. Philadelphia: University of Pennsylvania Press.

Coomaraswamy, R. (1999). Different but Free: Cultural Relativism and Women's Rights as Human Rights. In C. W. Howland (Ed.), Religious Fundamentalisms and the Human Rights of Women. New York: St. Martin's Press.

Donnelly, J. (1989). Universal Human Rights in Theory and Practice. Ithaca NY: Cornell University Press.

Elmadmad, K. (2002). Women's Rights under Islam. In W. Benedek, E. M. Kisaakye, \& G. Oberleitner (Eds.), The Human Rights of Women: International Instruments and African Experiences. London: Zed Books.

Elshtain, J. B. (1995). Exporting Feminism. Journal of International Affairs, 48(2).

Kisaakye, E. M. (2002). Women, Culture and Human Rights: Female Genital Mutilation, Polygamy, and Bride Price. In W. Benedek, E. M. Kisaakye, \& G. Oberleitner (Eds.), The Human Rights of Women: International Instruments and African Experiences. London: Zed Books.

Lange, L. (1993). Women Have to Exist to Resist: The Moral Worth of Persons and the Questions of Whether or Not Women are a Group. In D. Shogan (Ed.), A Reader in Feminist Ethics. Toronto: Canadian Scholars' Press Inc.

Mallick, K. (1998). Common Ground of Feminism and Cultural Relativism in Human Rights Discourse: The Case of Sex-determination Test in India. Philosophy and Gender. Retrieved March 5, 2013, from www.bu.edu.wcp/Papers/Gend/GendMall.htm

Mayer, A. E. (1995). Cultural Particularism as a Bar to Women's Rights: Reflections on the Middle Eastern Experience. In J. Peters, \& A. Wolper (Eds.), Women's Rights, Human Rights: International Feminist 
Perspectives. New York: Routledge.

Okin, S. M. (1994). Gender Inequality and Cultural Differences. Political Theory, 22(1). http://dx.doi.org/10.1177/0090591794022001002

Orend, B. (2002). Human Rights: Concept and Context. Peterborough ON: Broadview Press.

Peach, L. J. (2001). Are Women Human? The Promise and Perils of 'Women's Rights as Human Rights'. In L. S. Bell, A. J. Nathan, \& I. Peleg (Eds.), Negotiating Culture and Human Rights. New York: Columbia University Press.

Rao, A. (1995). The Politics of Gender and Culture in International Human Rights Discourse. In J. Peters, \& A. Wolper (Eds.), Women's Rights, Human Rights: International Feminist Perspectives. New York: Routledge.

Singer, M. (1999). Relativism, Culture, Religion and Identity. In C. W. Howland (Ed.), Religious Fundamentalisms and the Human Rights of Women. New York: St. Martin's Press.

Spelman, E. V. (1988). Inessential Woman: Problems of Exclusion in Feminist Thought. Boston: Beacon Press.

\section{Copyrights}

Copyright for this article is retained by the author(s), with first publication rights granted to the journal.

This is an open-access article distributed under the terms and conditions of the Creative Commons Attribution license (http://creativecommons.org/licenses/by/3.0/). 